University of Pennsylvania Carey Law School

Penn Law: Legal Scholarship Repository

Faculty Scholarship at Penn Law

$10-29-2020$

\title{
Toward Racial Equality: The Most Important Things The Business Community Can Do
}

Leo E. Strine Jr.

University of Pennsylvania

Follow this and additional works at: https://scholarship.law.upenn.edu/faculty_scholarship

Part of the Benefits and Compensation Commons, Business Administration, Management, and Operations Commons, Business Law, Public Responsibility, and Ethics Commons, Business Organizations Law Commons, Economic Policy Commons, Income Distribution Commons, Labor and Employment Law Commons, Labor Economics Commons, Law and Economics Commons, Law and Race Commons, Policy Design, Analysis, and Evaluation Commons, and the Social Policy Commons

\section{Repository Citation}

Strine, Leo E. Jr., "Toward Racial Equality: The Most Important Things The Business Community Can Do" (2020). Faculty Scholarship at Penn Law. 2230.

https://scholarship.law.upenn.edu/faculty_scholarship/2230

This Article is brought to you for free and open access by Penn Law: Legal Scholarship Repository. It has been accepted for inclusion in Faculty Scholarship at Penn Law by an authorized administrator of Penn Law: Legal Scholarship Repository. For more information, please contact PennlawIR@law.upenn.edu. 


\title{
Toward Racial Equality: The Most Important Things The Business Community Can Do
}

\author{
Conference Kickoff: Remarks by \\ Leo E. Strine, Jr.*
}

October 29,2020

\section{Conference on Racial Equity in Corporate Governance}

\author{
Co-Sponsored by: \\ Ira M. Millstein Center for Global Markets and Corporate Governance \\ Columbia Law School \\ The Institute for Law \& Economics \\ University of Pennsylvania \\ Arthur and Toni Rembe Rock Center for Corporate Governance \\ Stanford University \\ Stanford Center for Racial Justice \\ Stanford Law School
}

\footnotetext{
* Ira M. Millstein Distinguished Senior Fellow at the Ira M. Millstein Center for Global Markets and Corporate Governance at Columbia Law School; Michael L. Wachter Distinguished Fellow in Law and Policy at the University of Pennsylvania Carey Law School; Senior Fellow, Harvard Program on Corporate Governance; Henry Crown Fellow, Aspen Institute; Of Counsel, Wachtell, Lipton, Rosen \& Katz; former Chief Justice and Chancellor of the State of Delaware.
} 
I am honored to kick off this important series of discussions about what corporate governance and corporate America can do to reduce racial inequality and, more specifically, to help black people finally achieve equality after 400 years of systemic racism.

My only regret about this series is that it did not happen long ago. For most of the period since 1980 , there has been a steady erosion of our willingness to admit what a grievous injury we as a nation did to black people and the inadequacy, in both magnitude and durational commitment, of our nation's efforts to remedy that harm.

To be candid, all elements of the political spectrum and corporate America are to blame for that. Focusing on race was uncomfortable for white people of all political persuasions, and corporate leaders in particular. For certain people - like the members of the U.S. Supreme Court who struck down the Voting Rights Act and the ability of school districts to promote integration — two decades of remediation were more than enough, and it was time for black people to get over racial oppression themselves. For others, particularly on the left and in corporate America, there was a tendency to obscure discrimination against black people, and our failure to address racial inequality, by using the term diversity in a manner that was not wholly constructive but often more than a tad deceptive. 
Instead of promoting diversity and equal opportunity in general, but recognizing the compelling reasons why the United States had to make equality and opportunity for black people the most urgent priority, corporations and universities celebrated themselves for including elites who were not white and who did not suffer from the legacy of racial discrimination in the U.S. But, being blunt, hiring Ivy League law, business, and STEM graduates who had not suffered from the African-American experience and putting them - along with a bunch of white women and one black person - on the cover of glossy brochures did not help redress America's history of racism against black people. In many ways, branding of this kind was a way to put off dealing with it. For darn sure, it's great that the children of, for example, Asian and even black immigrants could take advantage of the equal opportunity provided by the Civil Rights Act of 1964, as could many within the African-American community's "talented tenth" who were fortunate enough to have college educations and more wealth, albeit while never being close to a tenth of African Americans. Ditto for the amazing progress of women and the LGBTQ community; it's tremendous and long overdue. But this progress did not heal the deeper wounds of our history of racism against black people. Rather, it just reflected the reality that our post-civil rights world did provide much greater opportunities for diverse people who had access to the right ladders of progress. 
For the bulk of black Americans, however, these ladders were beyond their grasp and thus a reminder of how unfair our society continued to be. And rather than continuing to shrink, as it had done when the New Deal/Great Society consensus was in place, racial inequality has grown sharply since the U.S. and our corporate governance system moved to embrace the belief systems of people who viewed racism and its effects as over and who put pleasing the stock market above all else.

Nothing in 2020 about these realities is new:

- $\quad$ Black people have incomes far lower than those of white and Asian Americans and depend almost wholly on their wages to survive and build wealth;

- $\quad$ Black people's wealth is even lower than that of white and Asian Americans, and black people have little stock ownership;

- Black children are more likely to rely on public schools;

- $\quad$ Black children are less likely to have experienced teachers and go to schools with adequate funding; and

- $\quad$ Black students are less likely to go to and complete college.

And this is to say nothing of how racism, sprawling and excessively punitive criminal codes, and the cruelty of poverty itself leads to a disproportionate number of black Americans being subject to the criminal justice system. 
2020 did not reveal anything new but did make it impossible for us to avoid a momentary mirror test:

- $\quad$ That people like George Floyd and Ahmaud Arbery were murdered;

- That essential workers necessary for our economy to function were paid far less than those of us who are not essential;

- $\quad$ That black workers were more likely to be essential and have to endanger themselves to keep a roof over their heads;

- $\quad$ That black workers suffered more unemployment; and

- That COVID-19 hit black people even harder than the rest of us.

Any moral person can’t deny the persistent inequality of our society now, and to be even more direct, all who did not understand that before should reflect on why it took this level of new suffering for black Americans to make them do so now.

Corporations and institutional investors are waking up, too. Finally, they embrace the need to include black people in the benefits of capitalism as a priority. Finally, they admit that economic inequality and its effect on black people matters.

So in the spirit of doing something positive about persistent racial inequality, three great centers of corporate governance at Columbia, Penn, and Stanford got out of their comfort zone and came together with the Stanford Racial Justice Institute to shed a little light. These influential institutions have brought policy 
experts, business leaders, and institutional investors together to help our corporate governance system in general, and corporations and institutional investors in particular, do their part to reduce racial inequality. I was proud to play a role in inspiring this collaboration, and applaud the leaders of the Millstein, Rock, ILE, and Racial Justice centers for putting together such an amazing array of talent to address this urgent issue.

Let me now underscore why the topic of this conference is so fundamentally important to the cause of racial justice.

Realizing how much more likely black people are to be among the working and lower-middle classes and how less likely they are to have investments in stock, imagine what progress might have been achieved had institutional investors and corporations made sure that workers continued to get their fair share of the gains from their hard work during the last 40 years? If the same share as workers had gotten in the era from 1945 to 1980 had been maintained, imagine how much that would have helped black people climb the economic ladder?

Imagine how better wages of that kind would have improved their chances to put their kids through college and build wealth to be passed on to the next generation? If corporations had given all workers, after paying a fair wage, $\$ 1,000$ toward their $401(\mathrm{k})$ and a match for the next $\$ 2,500$ ? Imagine just how much that could have closed the wealth gap? 
Realizing how much more likely black children are to depend on the public schools, imagine what progress might have been achieved if corporations had been willing to pay their school taxes as they did in the era before 1980? How much better could we have done by black students had corporations continued to pay their fair share instead of systematically seeking to exempt themselves from funding the public schools?

Realizing how much more likely black people and their children are to be segregated into urban and rural communities with high concentrations of poverty, imagine the progress that would have been made if businesses had made it a priority to put operations there, to fund their schools and give back to these communities?

Realizing how much economic insecurity contributes to the success of racially and ethnically divisive appeals, imagine if corporate America had supported a living wage, cooperated with instead of crushed unions, and given all workers their fair share of productivity gains in the former of higher pay, thus helping black people disproportionately while helping all struggling American workers? Imagine how that would have helped knit together the diverse fabric of our nation instead of tearing it apart?

Realizing how much more likely black Americans and white Americans without wealth are to be students at public universities, community colleges, and 
historically black colleges, imagine if corporate America had made real diversity a priority and sought to include American college graduates who were most economically disadvantaged?

Finally, realizing that the experience of being black in America is meaningfully different from that of being a recent immigrant since the Civil Rights Era, imagine if corporate America had kept a focus on achieving equality for black people first and foremost and not concealed their lack of progress toward that goal?

The sad truth is that, simply because institutional investors and corporations supported policies that shorted workers and the funding of public schools, racial inequality has grown.

So, as this constructive and novel series goes forward, let's not lose sight of the most important and fundamental things our business sector can do to help black people and our society become more equal. Include black people fairly in your recruiting, hiring, and promotional decisions. Recruit at the higher education institutions where black and less affluent Americans go. Pay fair wages, provide safe working conditions and family-friendly schedules, and help workers build wealth. Fund the public schools that black families depend on for their children to climb the economic ladder. Locate your operations in the communities where black people live and give back to them. And if you are an institutional investor, 
realize your duty to support these policies and fairness for all American workers, without whose sweat and productivity our capitalist system cannot work.

Sometimes it is that simple. What's hard is not determining the what, it's whether we all have the moral fiber to work together to make it happen. 